\title{
Histological Observation on Dental Hard Tissue Irradiated by Ultra-short Pulsed Laser
}

\author{
Takeyuki UCHIZONO, Akihiro IGARASHI*, Junji KATO*, \\ Yoshito HIRAI*, Daisuke MOHRI** and Kunio AWAZU \\ Graduate School of Engineering, Osaka University \\ (Chief: Prof. Kunio AWAZU) \\ * The Third Department of Conservative, Tokyo Dental College \\ (Chief: Prof. Yoshito HIRAI) \\ ** Department of Otorhinolaryngology, Osaka Dental University \\ (Received: February 28, Accepted for Publication: June 27, 2006)
}

\section{超短パルスレーザー照射による硬組織の組織学的評価}

\author{
内園岳志五十嵐章浩* 加藤 純二* \\ 平井義人*毛利大 介** 粟津邦男 \\ 大阪大学大学院工学研究科 \\ (主任：粟津邦男教授) \\ *東京歯科大学歯科保存学第 3 講座 \\ (主任 : 平井義人教授) \\ **大阪歯科大学耳鼻咽喉科
}

(受付：平成 18 年 2 月 28 日，受理：平成 18 年 6 月 27 日)

\begin{abstract}
要旨 : 近年, レーザーパルス幅がピコ秒からフェムト秒オーダーである超短パルスレーザーが様々な分野に応用されている。 このレーザーは, 最小限の熱影響で, 金属や半導体, 高分子材料そして生体組織を加工することが可能である。歯科分野におい て, 既存のレーザーシステムでの治療もしくは基礎研究から, 硬組織の熱影響またはクラック発生などの副作用が報告されてい る。記述した特性を持っている超短パルスレーザーは, このような問題の解決を期待できるため, 硬組織への超短パルスレー ザー照射効果の有効性が研究されている。本研究では, 歯牙硬組織への超短パルスレーザーの照射効果の有效性及び安全性を評 価するために，超短パルスレーザー照射前・後の歯牙硬組織の形態的な変化と光学的な変化を調べた。照射対象はプレート状に 加工したウシ歯エナメル質・象牙質であった。レーザーは，発振波長 $800 \mathrm{~nm}$ ，繰り返し周波数 $1 \mathrm{kHz}$ ，パルス幅 $130 \mathrm{fsec} の \mathrm{Ti}:$ sapphire レーザーを使用した。レーザーの平均パワー密度は，90，180，360W/ $\mathrm{cm}^{2}$ であった。レーザー照射後の対象の照射表面 はSEM と EDX を用いて評価した。対象の光学的変化の評価は, FTIR を用いた対象の吸収スペクトル変化の観察によって行っ た。SEM 観察によって，超短パルスレーザーの照射は，硬組織表面の炭化及びクラックを誘起せずに切削が可能であることが明 らかとなった。EDX 計測において，レーザー照射前・後の硬組織の $\mathrm{P} / \mathrm{Ca}$ は変化しておらず，また，FTIR 計測では赤外吸収ス ペクトルの変化は照射前・後で変化は見られなかった。レーザー照射の場合, これらの変化が起こる要因は, 主に熱的な影響で あることが報告されていることから，超短パルスレーザーは熱影響を最小限にして硬組織を切削できることが明らかとなった。

(J. Jpn. Soc. Laser Dent. $17: 81 \sim 86,2006$ Reprint requests to Dr. UCHIZONO)
\end{abstract}

Key words = Ultra-short pulsed laser, Ablation, Thermal damage

キーワード＝超短パルスレーザー，アブレーション，熱影響 


\section{Introduction}

Recently, ultra-short pulsed laser (USPL) has been extensively studied for ablating diverse materials such as metals ${ }^{1-3)}$, high-polymer materials ${ }^{4-6)}$, and biological tissue $^{7-8)}$ because USPL can ablate materials with minimal thermal damage. In the field of dentistry, lasers are used to remove carious dental hard tissue and for cavity preparation of dental hard tissue because they offer several advantages such as no pain, no noise and low-invasiveness, over the dental high-speed drill. However, it has been reported that irradiation with the conventional laser system induces thermal damage such as carbonization and micro-cracks ${ }^{9-12)}$ in dental hard tissue. These side effects occur because the laser pulse duration is longer than the thermal relaxation time of tissue. In other words, a laser pulse, which is of shorter duration than the thermal relaxation time of tissue, can ablate tissue without thermal side effects. Therefore, USPL, which has the laser pulse duration of femto ${ }^{10-15)}$ to pico $^{10-12)} \mathrm{sec}-$ onds, is expected to remove carious dental hard tissue and cavity preparations of dental hard tissue without thermal side effects. In fact, Niemz has demonstrated the effectiveness of USPL irradiation in dentistry in principle ${ }^{13)}$. He clarified that USPL irradiation caused no thermal damage to dental hard tissue using Nd:YLF picosecond laser. In addition, Weigl et al. studied the application of USPL to dentistry with Ti:sapphire laser of femto second pulse duration ${ }^{14)}$. However, they have not investigated the optical changes of samples irradiated with USPL, although such measurements are commonly made in basic research of laser dentistry. In this paper, we examine the optical change of samples irradiated with USPL and observe dental hard tissue irradiated with USPL.

\section{Materials and Methods}

\section{Ti:sapphire femto second laser}

Ti:sapphire laser (hariccain, Spectra-Physics, Inc.) was used in this study. The laser had a wavelength of $800 \mathrm{~nm}$, pulse duration of 130 femtosecond, pulse repetition rate of $1 \mathrm{kHz}$, and average power density of 90,180 , $360 \mathrm{~W} / \mathrm{cm}^{2}$. These average power densities were measured using power meter (Model 407A, Spectra-Physics, Inc.). Laser spot size was $200 \mu \mathrm{m} \times 200 \mu \mathrm{m}$, which was calculated by theoretical analysis of lens focus number.

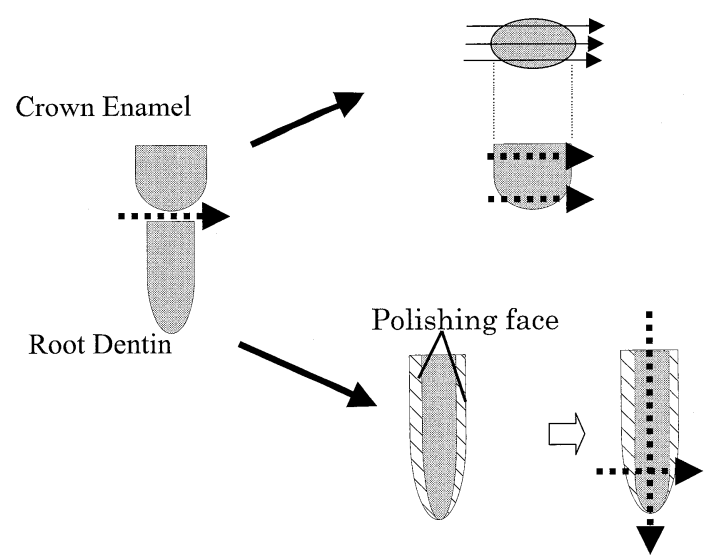

Figure 1 Separation method of enamel and dentin. Separation of dental enamel and dentin was achieved using diamond cutter

\section{Tooth preparation}

The tooth used for this study was enamel plates and root dentin plates of extracted bovine teeth. Figure 1 shows the separation method of enamel and root dentin. These plates were processed to the size of $1 \times 2 \times 0.5$ (cm) using a cutter. The surfaces of plates were polished using sandpapers of \#400 to \#1200. N numbers of samples were each subjected to laser irradiation three times. These plates were irradiated with USPL using a stage moving at $1 \mathrm{~mm} / \mathrm{sec}$.

Morphological and histological observation of irradiated dental hard tissue

A scanning electron microscope (SEM) was used to examine the morphological change of irradiated sample. The observation part were the surface and the cross surface of irradiated samples. SEM images of samples were observed at an applied voltage of $20 \mathrm{kV}$ after the samples were evaporated with platinum.

Energy dispersive X-ray analysis (EDX) was used for examining the histological change of irradiated sample. EDX can determine quantitatively the structural composition of objects. In this study, the histological changes of irradiated samples were determined by comparing the phosphorus (P)/calcium (Ca) ratio of irradiated samples with those of non-irradiated samples.

\section{Measurement of optical change}

Fourier Transform Infrared Spectroscopy (FTIR) was used to observe the optical change of samples irradiated with USPL. FTIR can measure the optical absorption of objects, spectrally. The measurement conditions of FTIR were a resolution of $2 \mathrm{~cm}^{-1}$ and gain of 4 . The 

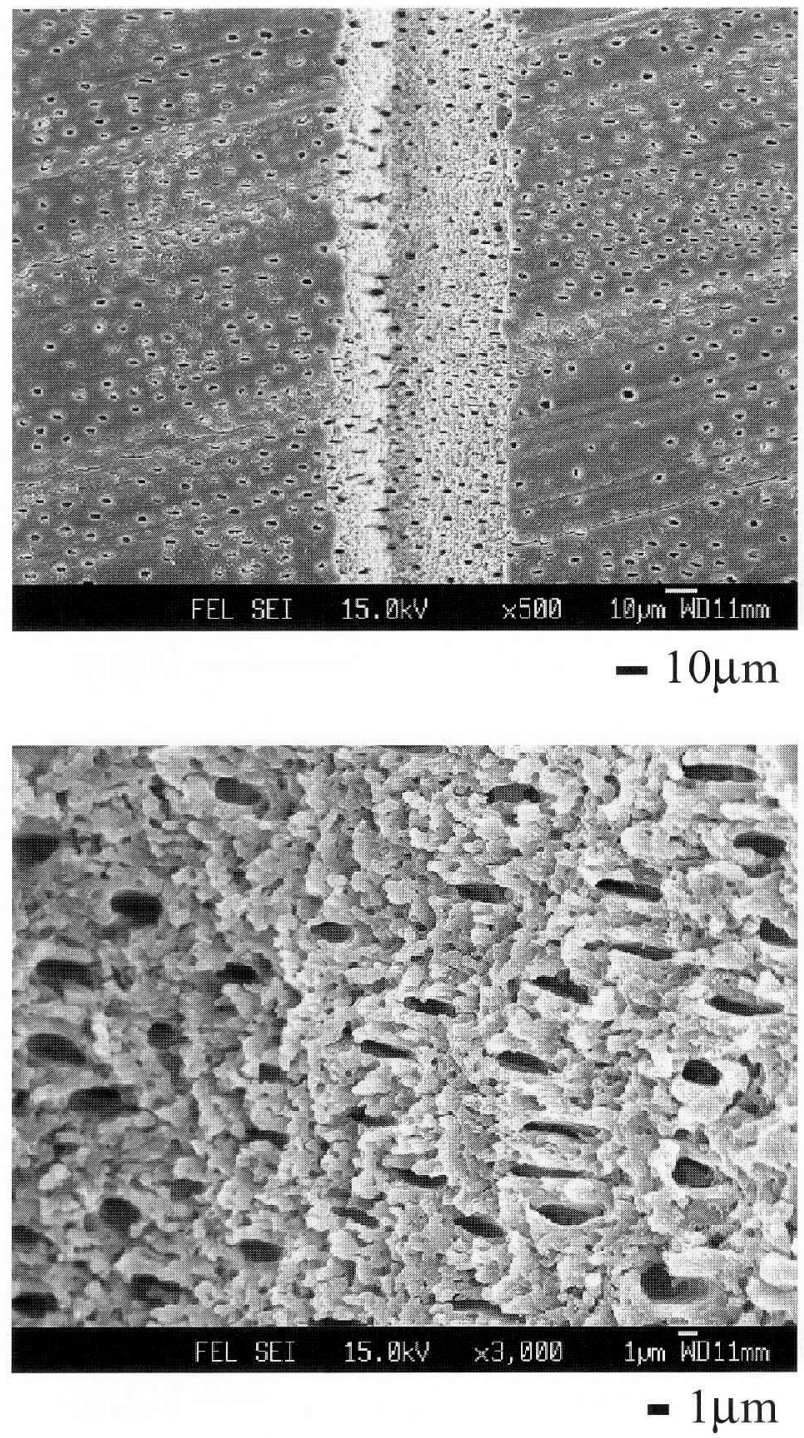

Figure 2 SEM image of the dentin samples irradiated with ultra-short pulsed laser. In the upper image, magnification is $\times 500$ and bar is $10 \mu \mathrm{m}$. In the lower image, magnification is $\times 3000$ and bar is $1 \mu \mathrm{m}$

optical change of irradiated sample was determined by comparing the absorption spectrum of irradiated samples with non-irradiated samples.

\section{Result}

Figure 2 shows the surface of a dentin sample irradiated with USPL. The dentin was sharply and straightly ablated by scanned laser irradiation, not roughly like Er: YAG laser. In addition, dentinal tubules were opened clearly. There was no smear layer or carbonized layer on the surface of irradiated dentin.

Figure 3 shows the cross section of a dentin sample ir-

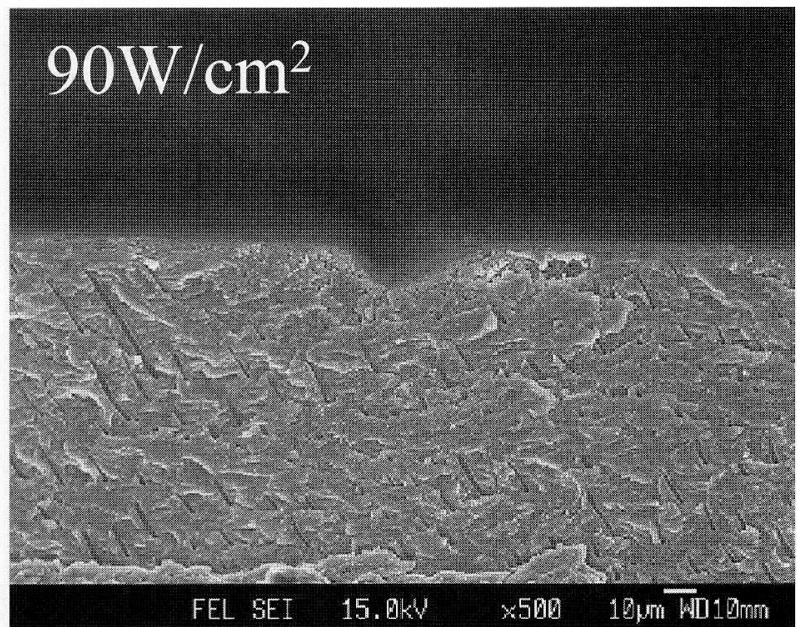

\section{$180 \mathrm{~W} / \mathrm{cm}^{2}$}

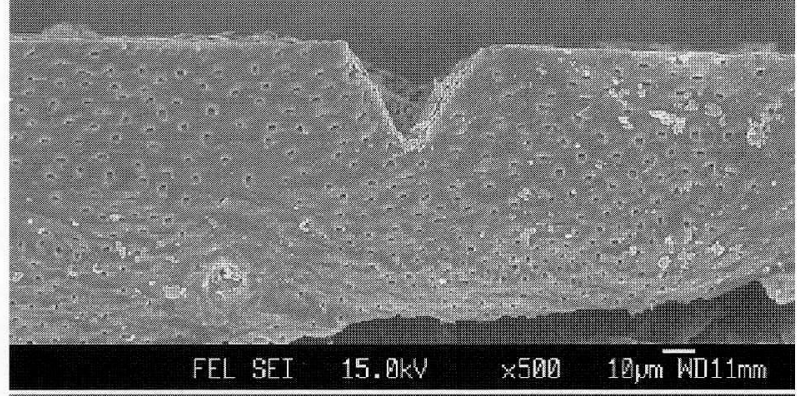

$360 \mathrm{~W} / \mathrm{cm}^{2}$

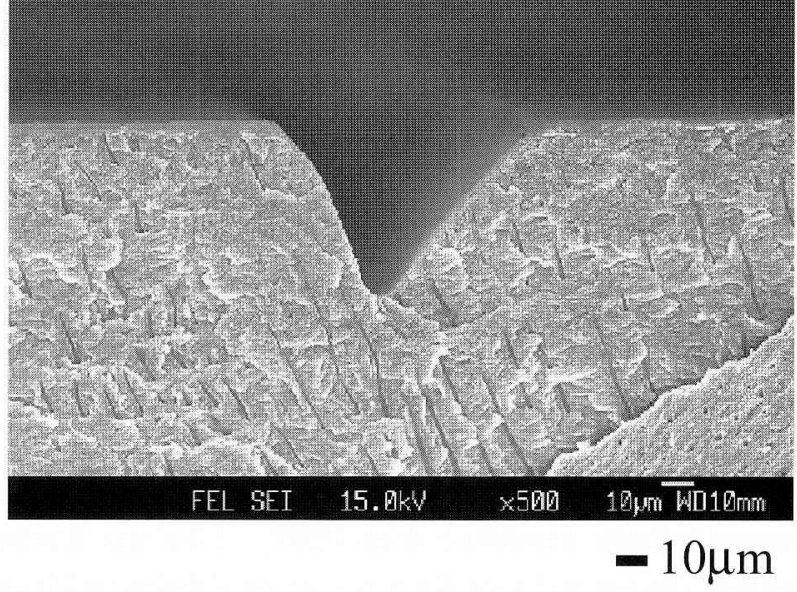

Figure 3 SEM image of the cross section of dentin samples irradiated with ultra-short pulsed laser. In all images, the magnification is the $\times 500$. Average power densities are $90 \mathrm{~W} / \mathrm{cm}^{2}$ (upper), 180 $\mathrm{W} / \mathrm{cm}^{2}$ (middle), and $360 \mathrm{~W} / \mathrm{cm}^{2}$ (lower) 

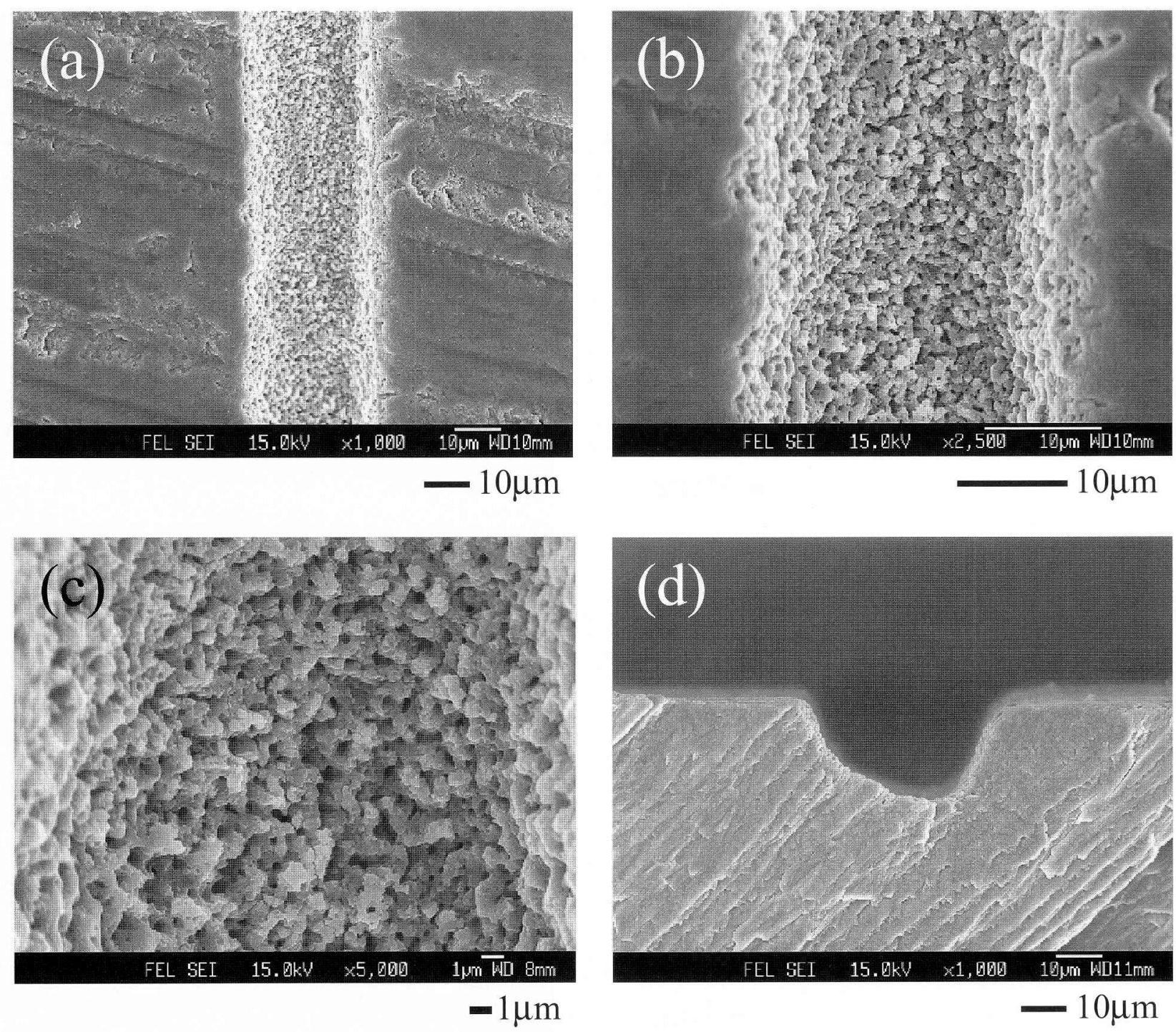

Figure 4 SEM image of the surfaces and cross section of enamel samples irradiated with ultra-short pulsed laser. Each image has a magnification of $\times 500$ (a), $\times 2500$ (b), $\times 5000$ (c), and $\times 1000$ (d). Images (a), (b), and (c) show the surface enamel irradiated with USPL. Image (d) is a cross section

radiated with USPL at $90,180,360 \mathrm{~W} / \mathrm{cm}^{2}$. The ablation depth by USPL irradiation increased in proportion to the laser power density. Dentin fragments and micro-cracks were not observed on the irradiated samples.

Figure 4 shows the surface and cross section of an enamel sample irradiated with USPL. Like the dentin sample, the enamel samples have sharp ablation, without smear layer, carbonized layer, or crack.

The change of mass percent of irradiated samples is negligible as shown in Table 1. There was no significant difference between the irradiated sample and the non-irradiated sample, both for the dentin sample and enamel sample, by the t-test $(\alpha=0.05)$.
Table 1 Mass percent of $\mathrm{P} / \mathrm{Ca}$ by EDX measurement. "Irradiated dentin or enamel" means the samples irradiated with femto second laser. "Control dentin or enamel" means non-irradiated samples

\begin{tabular}{ll}
\hline \multicolumn{2}{c}{ Mass percent of $\mathrm{P} / \mathrm{Ca}$} \\
Samples & Ratio of $\mathrm{P} / \mathrm{Ca}$ \\
\hline Control dentin & $0.488 \pm 0.01$ \\
Irradiated dentin & $0.484 \pm 0.013$ \\
Control enamel & $0.468 \pm 0.006$ \\
Irradiated enamel & $0.462 \pm 0.008$ \\
\hline
\end{tabular}

Error is standard deviation of 10 measurements 

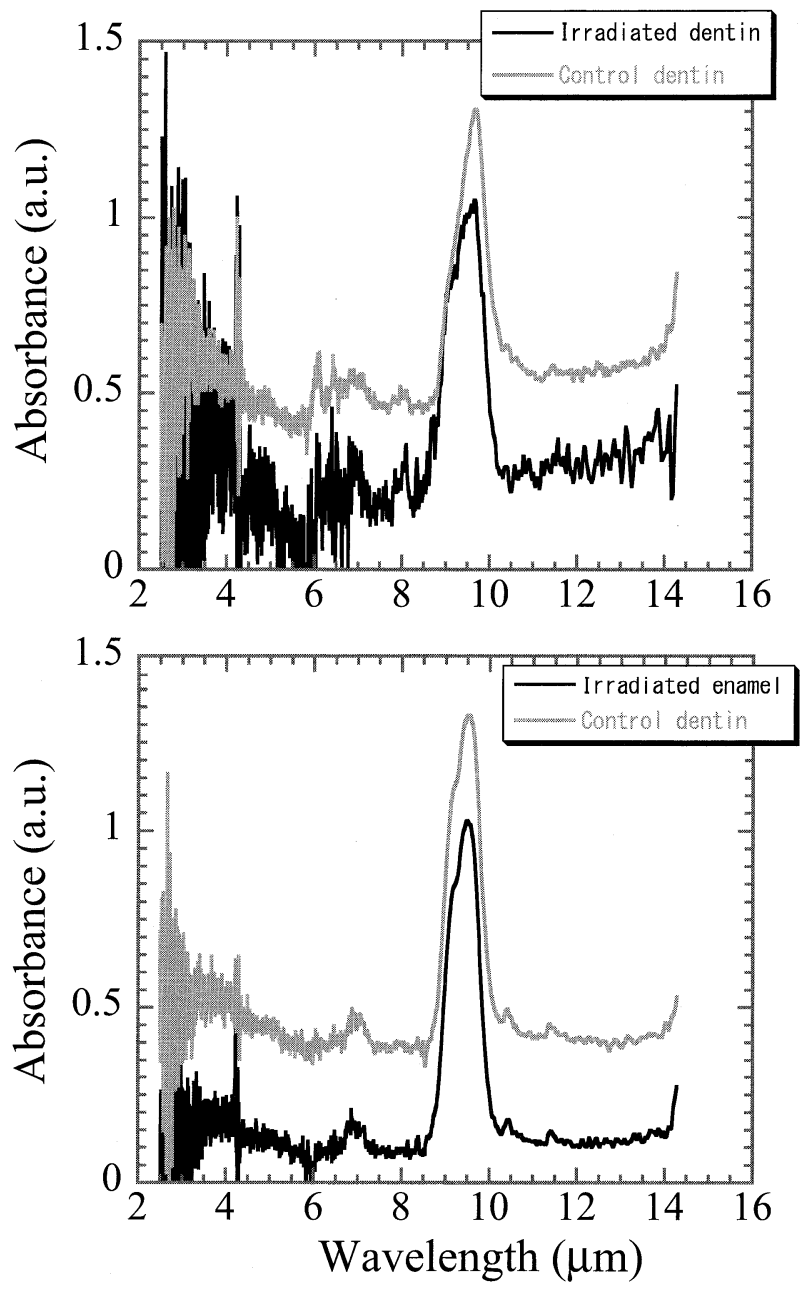

Figure 5 IR spectrum of the irradiated sample. The upper spectrum is for the dentin irradiated with USPL and non-irradiated dentin. The lower spectrum is the case of enamel samples

Figure 5 shows the infrared absorption spectrum of irradiated samples and non-irradiated samples. There was no change in the absorption peak of $\mathrm{PO}_{4}^{2-}$, which is a steep peak in the $9 \mu \mathrm{m}$ region, between the irradiated sample and non-irradiated sample, both for the dentin and enamel. In addition, the peak of $6 \mu \mathrm{m}$ region had no change and no shifting, too. These peaks are amideI, amideII.

\section{Discussion}

Laser ablation of dental hard tissue can be achieved using Er:YAG laser and the $9 \mu \mathrm{m}$ region $\mathrm{CO}_{2}$ laser that is absorbed in $\mathrm{PO}_{4}^{2-}$ of hydroxyapatite ${ }^{15)}$. However, it has been reported that laser pulse duration, which is longer than the thermal relaxation time of dental hard tissue, lead to thermal side effect to teeth. These thermal side effects can be observed by morphological, histological, and optical measurement, etc. In morphological measurement such as SEM, thermal side effects can be observed as a carbonized layer and thermal cracks. Histological observation such as EDX can confirm thermal effects by observing the change of $\mathrm{P} / \mathrm{Ca}$ ratio in dental hard tissue. Optical measurement such as FTIR can observe thermal side effects by comparing the spectrum of an irradiated sample with that of a non-irradiated sample. Niemz and Weigl has shown the ablation method that had the no thermal side effect to ablated dental hard tissue using ultra short pulsed laser such as pico, femtosecond laser ${ }^{13,14)}$. They used morphological measurement mainly. In this study, we investigated ultra-short pulsed laser-dental hard tissue interaction using FTIR as optical measurement, EDX as histological measurement, and SEM. These measurements showed no optical change, no crack, no carbonized layer, no change of $\mathrm{P} / \mathrm{Ca}$ ratio, and opened dentinal tubules. From these results we confirmed that the ultra-short pulsed laser can ablate dental hard tissue with no crack, no fragment, and no thermal damage. These results confirm the reports ${ }^{13,14)}$ and are expected to resolve the thermal side effects to hard tissue caused by the conventional laser.

Tooth dentin consists of $70 \%$ hydroxyapatite, $12 \%$ water, and $18 \%$ organic matter. On the denaturation of organic matter, it has been reported that ultra-short pulsed laser could ablated the brain sample as organic matter with no thermal side effect ${ }^{7}$. In addition, we had confirmation of the no change of absorption peak of $6 \mu \mathrm{m}$ region in the dentin samples. These evidences confirm that ultra-short pulsed laser has not the thermal side effect on soft tissue.

It has been reported that the solution layer of dental hard tissue surface irradiated with conventional laser such as $\mathrm{CO}_{2}$ can increase the acid resistance of dental hard tissue ${ }^{16)}$. However, USPL is not expected increase of acid resistance because the sample surface irradiated with USPL had no solution layer.

\section{Conclusion}

The effectiveness of ablation on dental hard tissue using an ultra-short pulsed laser (USPL) was investigated by morphological, histological, and optical observations. The results clarified that:

1) There was no optical change of dental hard tissue after USPL irradiation. 
2) The dental hard tissue was ablated, sharply.

3) Dentinal tubules were clearly opened at the surface of irradiated dentin.

4) Carbonization and cracks were not observed in the irradiated samples. Therefore, USPL is expected to use as an ablation method without causing thermal damage to dental hard tissue. Future studies will be needed to clarify the relationship between laser energy and ablation ability with USPL, and the effectiveness of ablation for carious teeth.

\section{Reference}

1) Wellershoff SS, Hohlfeld J, Gudde J, et al: The role of electron-phonon coupling in femtosecond laser damage of metals. Appl Phys A, 69(Suppl.) : S99-S107, 1999.

2) Corkum PB, Brunel F, Sherman NK: Thermal Response of Metals to Ultrashort-Pulse Laser Excitation. Phys rev Lett, $61: 2886-2889,1988$.

3) Kautek W, Kruger J, Lenzner M, et al: Laser ablation of dielectrics with pulse durations between 20 fs and 3 ps. Appl Phys Lett, 69 : 3146-3148, 1996.

4) Du D, Liu X, Korn G, et al: Laser-induced breakdown by impact ionization in $\mathrm{SiO}_{2}$ with pulse widths from 7 ns to 150 fs. Appl Phys Lett, 64 : 3071-3073, 1994.

5) Stuart BC, Feit MD, Herman S, et al: Nanosecond-to-femtosecond laser-induced breakdown in dielectrics. Phys rev B, $53: 1749-1761,1996$

6) Kumagai $\mathrm{H}$, Midorikawa $\mathrm{K}$, Toyoda $\mathrm{K}$, et al: Ablation of polymer films by a femtosecond high-peak-power Ti:sapphire laser at $798 \mathrm{~nm}$. Appl Phys Lett, 65 : 1850-1852, 1994.
7) Loesel FH, Fischer JP, Gotz MH, et al: Non-thermal ablation of neural tissue with femtosecond laser pulses. Appl Phys B, $66: 121-128,1998$.

8) Feit MD, Rubenchik AM, Joslin EJ, et al: Influence of pulse duration on ultrashort laser pulse ablation of biological tissues. J Biomed opt, 6 : 332-338, 2001.

9) Fried D, Ashouri N, Breunig T, et al: Mechanism of water augmentation during IR laser ablation of dental enamel. Lasers Surg Med, 31 : 186-193, 2002.

10) Keller U, Hibst R: Experimental studies on the application of the Er:YAG laser on dental hard substance: II. Light microscopic and SEM investigation. Lasers Surg Med, $9: 345^{-}$ 351, 1989.

11) Lee C, Ragadio J, Fried D: Influence of wavelength and pulse duration on peripheral thermal and mechanical damage to dentin and alveolar bone during IR laser ablation. SPIE proc, 3910 : 193-203, 2000.

12) Cecchini RCM, Zezell DM, Oliveira ED, et al: Effect of Er: YAG Laser on Enamel Acid Resistance: Morphological and Atomic Spectrometry Analisis. Lasers Surg Med, 37 : 366372, 2005.

13) Niemz MH: Investigation and spectal analysis of the plasma-induced ablation mechanism of dental hydroxyapatite Appl Phys B, 58 : 273-281, 1994.

14) Weigl P, Kasenbacher A, Werelius K: Dental Applications, Dausinger Friedrich, Lichtner Friendmann, and Lubatschowski Holger, Femtosecond Technology for Technical and Medical Applications, 1 st ed, Berlin, 2004, Springer. 167-186.

15) Fried D: IR laser ablation dental enamel. SPIE proc, 3910 : 136-148, 2000.

16) Featherstone JDB, Barrett-Vespone NA, Fried D, et al: $\mathrm{CO}_{2}$ laser inhibition of artificial caries-like lesion progression in dental enamel. J Dent Res, 77 : 1397-1403, 1998. 